\title{
Indigeneity as Resistance
}

\author{
Ilan Pappe
}

"We are not red Indians," Yasser Arafat declared when presented for the first time with the notion of Palestinians as an indigenous people. ${ }^{1}$ Understandably, the leader of the Palestine Liberation Organization (PLO) dreaded the political implications of comparing the Palestinians to indigenous groups who had lost the struggle for sovereignty and independence, particularly to a group that had been enclaved in reservations and pushed to the social and geographical margins of the American reality. A group, one should hasten to remark, that nonetheless is still struggling and has not, all in all, accepted defeat.

This chapter deals with the delicate relationship between nationalism and indigeneity, and specifically in the north of historic Palestine. It begins by revisiting the common apprehension, articulated above by Arafat, about framing the Palestinian struggle as an indigenous one. By now, this issue has been addressed by the rich scholarship that applies the settler-colonial paradigm to the case study of Palestine. In this literature, the Zionist project, and the state of Israel, are presented as clear examples of a settler-colonial movement, implying that if the Zionists are the settlers, the Palestinians are the indigenous people of the land. What this indigeneity means and how it relates to the Palestinian national struggle is an ongoing discussion among academics and activists, one that will contribute significantly to the meaning of political struggle for liberation in this century.

This chapter claims that the people who have carried out the Palestinian struggle within the state of Israel in recent years articulate, by their actions, aspirations, and visions, their own version of a national indigenous struggle for liberation. At the heart of this struggle is the wish to decolonize historic Palestine as a whole, while being willing to achieve this incrementally and from below. It is an approach quite different from other modes of Palestinian resistance, such as the ones carried out in the past and the ones chosen by Palestinians in the Gaza Strip and the West Bank.

My central contention here is that indigeneity has become a signifier of cultural and political Palestinian struggle within the state of Israel, with possible 
implications for Palestinians in parts of the West Bank, in Areas B and C, and the greater Jerusalem area. It is important to stress that indigeneity is not treated here as a fixed identity but rather as a dynamic one that activists articulate and grow into. $^{2}$ This particular resistance complements current modes of existence and resistance among the Palestinian community in Israel. In view of recent political developments in Israel and the choices confronting the Palestinian community, indigeneity is unfolding as a powerful tool that can enhance the project of the liberation of Palestine as a whole, and of the Palestinians in Israel in particular. This does not mean that it would be possible to liberate Palestine fully without a total dismantlement of the Zionist institutions of the Jewish state and the creation of one democratic state as the endgame of this struggle. The discourse and practice of indigeneity described here help shed light on new ways to reach this goal.

\section{INDIGENEITY AS AN ALTERNATIVE \\ POLITICAL DISCOURSE}

Ever since indigeneity became an analytic prism for explaining the Palestinian struggle, it has been a bone of contention within the area of Palestinian studies. The origins of the debate are a bit peculiar. It should have been triggered by the almost unanimous scholarly embrace of the settler-colonial paradigm as the paradigm for understanding the Palestinian condition, given that the embedded logical assumption is to define the Palestinians as either natives or indigenous in view of the fact that the Zionists are settlers. However, the indigeneity debate was instead prompted when scholars started to study one particular group of Palestinians: the Bedouins of the Naqab. ${ }^{3}$ Many nationalists feared that using such a framework of analysis would differentiate one Palestinian group from another and thereby contribute to fragmentation of the Palestinian people through what one scholar called "divisive classification." The danger is that such a practice will tally with Israeli policies of dividing the Palestinians into religious and cultural minorities, thereby questioning their cohesive national identity.

However, the debate surrounding the applicability of the discourse of indigeneity to the Palestinians is not simply an academic one. The principal conceptual concern among scholars who object to this designation lies in the limited nature of the UN Declaration on the Rights of Indigenous Peoples (adopted in 2007) when applied to the Palestinian struggle, as this declaration does not include a clear endorsement of a people's right to independent statehood. It is also possible that those scholars have reservations regarding the use of the prism of indigeneity when it comes to describing the Palestinian struggle because of some preconceived dominant stereotypes concerning the "primitivism" and vulnerability of indigenous people. ${ }^{5}$

One of the most detailed challenges to the indigeneity framework was voiced by Nadim Rouhana. ${ }^{6}$ He claimed that the Zionist settler-colonial project was different 
from what he called "triumphant" settler-colonial projects-in which the natives were conquered and subdued, as in North America and Australia. Since Zionism has not as yet "triumphed," the struggle against it is still national, including for the Palestinians inside Israel. He therefore prefers to use the term "homeland nationalism" to designate the efforts of Palestinians in Israel to reclaim Palestine as their national homeland. For Rouhana, this "homeland nationalism" complements the broader Palestinian nationalism of claiming Palestine as the homeland of the Palestinian people.

I believe that the political nature of the Palestinian struggle can be enriched by incorporating the concept of cultural indigenous resistance into it, in particular at a time when there is no space or scope for the notion of armed struggle. As Edward Said had clarified, culture is political, especially when we focus on an expanded, rather than narrow, definition of what culture is. The narrow definition relates to the aesthetic and literary assets of a society: "Culture is a concept that includes a refining and elevating element, each society's reservoir of the best that has been known and thought." The expanded definition of culture, by contrast, sees it as the theatre of life "where various political and ideological causes engage one another." Culture, in the eyes of the settler state, is defined within the narrow definition put forward by Said. For the indigenous population, it is understood within the expanded version.

This chapter contends that the indigenous cultural struggle is not an antithesis, or alternative, to the political national one, but rather the optimal struggle available, in view of the historical junction the Palestinian question finds itself in. An indigenous cultural struggle is, in its essence, part of a political resistance, especially given that other modes of resistance have not been very successful so far. As pointed out by Amara, framing the Palestinian people within the settlercolonial paradigm is a "manifestation of a resistant approach to the Palestinian political project" of state formation. ${ }^{8}$ The Palestinian wish for decolonization remains the same, but the nature of the struggle has changed.

There is a growing recognition among other Palestinian scholars that Palestinians share a common fate with quite a few indigenous peoples. According to Rana Barakat, this shared fate with other indigenous people should be the focus of Palestinian research on settler-colonialism moving forward. She argues that it is time to leave aside the already saturated deconstruction of Zionism as a settler-colonial movement and focus instead on the potency of indigeneity as a conceptual and political framework moving forward. ${ }^{9}$ Her views are in line with the useful comparisons that Mahmoud Mamdani makes between the Native American and Palestinian predicaments. Mamdani suggests that in both cases the main struggle between the settler states and the natives is about citizenship and land. ${ }^{10}$ Both indigenous communities (and here he refers not necessarily to Palestinians in general, but specifically to those in Israel) have employed legal and civil means to change their status within the settler state. The legal struggle for citizenship rights 
in both contexts reflects the settlers' view of indigeneity: American Indians were "declared" citizens in 1924 with the Indian Citizenship Act, thus they were considered naturalized citizens, as distinct from those who gained citizenship rights through birth. Palestinians in Israel were declared citizens by means of a similar act, the 1952 Nationality Law. This law immediately created two types of citizenship: one for Jews by virtue of a "birthright," and one for Palestinians by a process akin to naturalization. In both cases, the natives were depicted, or framed, by the settlers as aliens who needed to be naturalized. The struggle against this particular injustice can be therefore better understood within the field of native and indigenous studies than within conventional national or nationalist paradigms. ${ }^{11}$

Those who insist on employing indigeneity as a useful lens to interpret the reality of the Palestinians in Israel stress that the application of the indigenous framework does not affect the subjective Palestinian sense of identity. Indigeneity stems from a more complex and dialectic process in which native people respond to their role or place within the settler-colonial narrative and policies. Thus, the comparison to Native Americans does not focus on the success or failure of the settlercolonial project of eliminating the natives but compares their place (or rather their absence) within the ethos of settlers' communities: their construction as the savage Native Americans who will disappear with the completion of the "errand in the wilderness" of the white settlers in North America and the primitive Arabs who will wilt under the Zionist project of "blooming of the desert." 12 This process has profound impacts on Israeli policies and the Palestinian community in Israel, since it reflects not simply an assault on Palestinian national dignity, as Rouhana argues, but also a threat to their indigenous survival. ${ }^{13}$

\section{INDIGENEITY AS A POLITICAL STRATEGY}

Israeli politics has undergone a drastic transformation since the collapse of the Camp David negotiations in 2000. The Israeli regime has become more nationalist, religious, and extreme. The orientation is towards a unilateral expansion of the state over the Occupied Territories and a fierce struggle against any manifestation of Palestinian national sentiment or agenda within areas defined as Israel proper. This new attitude has been legalized through the Jewish Nation-State Basic Law in July 2018. Meanwhile, Israeli processes of land expropriation, informal and formal annexation, and the imposition of Israeli law in various parts of the West Bank have inflicted a final deathblow to the Israeli Palestinian "peace process" and to the chances of a two-state solution.

Within Palestinian politics, as well as in the scholarly world, however, a clear distinction continues to be made between the Palestinian struggle for statehood in the West Bank and the Gaza Strip and the Palestinian civic struggle inside Israel. To this day, the Palestinian leadership on both sides of the Green Line, notwithstanding their cooperation and constant dialogue, regard their struggles as distinct 
and different. ${ }^{14}$ The implication of such a position is that Palestinian citizens in Israel are not present in the classical anticolonialist struggle to achieve an independent state, which those in the Occupied Territories still hope to attain. As 'Azmi Bishara commented years ago, the Palestinian strategy in Israel has never been about destroying the Jewish state from within or about gaining sovereignty. ${ }^{15}$

These debates reveal the importance of clearly distinguishing between the terms indigenous and native, which activists tend to use interchangeably. In this chapter, native is a more neutral, static term, almost an ecological statement, that defines a group's location and attachment. Indigenous, on the other hand, is an evolving position of empowerment and resilience against the oppression that natives face. It is the political framework in which communities express their national, or group, identity. In this regard, the Palestinians in Israel are indigenous, native, and a national minority. They are separated from the other Palestinian groups and yet are reintegrated with the Palestinians in the West Bank by virtue of Israel's policies of expansion and colonization, which continue within the Green Line and outside it. ${ }^{16}$

Affirming national identity undoubtedly can entail affirming the Palestinian right to their own state next to Israel. However, the claim for indigenous rights goes beyond a claim for a sovereign state over 22 percent of one's homeland. It refers to the historical homeland in its totality as much as entails a demand for redistributing land ownership and wealth. When it becomes part of a campaign for a change of regime from the Jordan River to the Mediterranean, it is also an aspiration to dismantle settler-colonial institutions as well as reshape the debate surrounding state immigration policy and its symbolic nature. An incremental political, cultural struggle in line with such a vision can produce partial but meaningful achievements, even without bringing about a change of sovereignty, as can be seen in other parts of the world. ${ }^{17}$

The visions that one has of the future, or of the possible political solutions available, undoubtedly impact, consciously or unconsciously, one's understanding of the present. For Palestinians inside Israel, be they activists, scholars, or both, full independence, that is, complete territorial decolonization, is not a realistic goal. In such a context, indigeneity becomes another form of self-assertion against the settler state of Israel. Willingness to adopt indigeneity as a social and political framework of resistance is more clearly evident, and acceptable, among the Palestinian community inside Israel than among the Palestinians in the Occupied Territories, where quite a few still adhere to a national liberation agenda that seeks the creation of an independent Palestinian state next to Israel.

This willingness to define oneself as indigenous can clash with more explicit national self-definition. Yet, the tension that the Palestinian population inside Israel has felt between these two definitions has been eased in recent years. This is largely due to two developments: on the one hand, the despair that many feel regarding the prospect of substantial political solutions, or a viable Palestinian 
state, in the foreseeable future, and on another hand, a determination to work more locally and less ambitiously against a settler state that with every passing year becomes less tolerant and more discriminatory. Both processes, political despair and bottom-up activism, have meant that activists are avoiding macro-level political and ideological projects and focusing instead on tangible actions that protect the Palestinian community.

It is important to note, though, that the transition from political to cultural activism that various activists are embarking on is not part of a conscious attempt to substitute, or avoid, the need to redefine the Palestinian liberation project moving forward. It is rather a pragmatic adaptation to an ongoing struggle in light of the failure of one hundred years of resistance to liberate the homeland and given the existential threats that the neo-Zionist state of Israel poses to Palestinians in the twenty-first century.

There is also another impulse encouraging a new civil and scholarly understanding of the Palestinian struggle. It is the wish not to repeat past failures such as the unsuccessful attempt to internationalize the struggle of the Palestinians in Israel. Neither the PLO nor Israel allowed the case of the Palestinians in Israel to be discussed in the peace process. The international community regarded the relationship of the Jewish state with its Palestinian minority as a domestic issue pertaining to those living inside Israel. The PLO in the 1970s explained this exclusion of the Palestinians in Israel from its overall national struggle by stating that each group of Palestinians knew best what kind of a struggle it should conduct according to its specific context. This has never undermined the PLO's standing among Palestinians in Israel as is so accurately and beautifully manifested in the poetic correspondence between Mahmoud Darwish and Samih al-Qassem. ${ }^{18}$

Within the framework of the conventional Palestinian national struggle, the Palestinians in Israel did not constitute a matter of international concern, but were a domestic Israeli problem. Framing this minority as indigenous enables it to be associated with the global struggle of indigenous people, and therefore internationalizes its cause. The international dimension of the comparative study on indigeneity was highlighted by the case of Steven Salaita, a Palestinian scholar in the United States who compared American Indian literature and political history with that of Palestine. ${ }^{19}$ In his work, and in the campaign that ensued in the wake of a university decision to withdraw its offer of employment on ideological grounds, the international connection between the victims of both settler-colonial projects showed that academically and politically this is a valid and useful struggle. It recruited many in the complex matrix of American ethnicity and multiculturalism to the Palestinian struggle, though in the past they had been distanced from it. The connection had been recognized before, due to Edward Said's influence on native studies in America and his twin scholarship on Orientalism and Palestine, which reinforced these links and made them a potent factor in the struggle for Palestine in American and international public spaces. 
The recognition of this international dimension can be seen in the United States, where efforts to draw parallels and organize joint solidarity activities between indigenous and Palestinian groups have intensified over the past years. For example, the Palestine Youth Movement of San Diego and Collectivo Zapatista came together in Fall 2013 for a five-kilometer run along the US-Mexico border, to show the parallels between the settler-colonial projects in Mexico and Palestine. ${ }^{20}$

This being said, it is important to make a clear the distinction between indigeneity as understood within the liberal Zionist position, which grants cultural autonomy to Palestinians, and the nature of the indigenous cultural struggles described here. Liberal Israeli bodies such the mainstream Israeli Association for Civil Rights see their mobilization on behalf of Palestinian citizens in recent years as a struggle over the soul of Israeli democracy. In this they are similar to the anti-occupation Jewish movement, which wished to end the occupation because of the moral damage it causes to the Jewish state. The indigenous struggle for the Palestinians in Israel, however, centers on Palestinian attachment to the land. The Israeli democracy, or alleged democracy, can hide its settler-colonial nature in many aspects of life, but not on the question of land ownership. As the Palestinians in the north of Israel say, the land speaks Arabic in the Jewish state.

Palestinian engagement with Israeli democracy is not an end in itself, but a means of ensuring first of all the survival of the indigenous population, then its equality, and finally its role in shaping the future solution of Israel/Palestine. As the discussion below shows, the projects initiated by Palestinian citizens of Israel to assert their rights to the land and to equality are part of an indigenous cultural and political resistance now taking precedence over old forms of resistance such as armed struggle or state-building. These young Palestinians navigate carefully between respect for the national struggle and its legacy, on the one hand, and the need to find new forms of struggle, on the other.

\section{INDIGENOUS PALESTINIAN STRUGGLES WITHIN}

ISRAEL: CULTURE AS POLITICAL RESISTANCE

Cultural resistance has become quite a common scholarly reference in cultural studies, one that is "located in countless non-heroic practices that make up the realm of the everyday and its multiple connections with contemporary global life," as Roland Bleiker put it. ${ }^{21}$ Cultural resistance underscores how various cultural practices are employed to contest and combat a dominant power, often constructing a different vision of the world in the process. As Gramsci pointed out, power resides not only in institutions, but also in the ways people make sense of their world; hegemony is a political and cultural process. ${ }^{22}$ Armed with culture instead of guns, one fights a different type of battle. Whereas traditional battles were "wars of maneuver," frontal assaults that seized the state, cultural battles are "wars of 
position," flanking maneuvers, commando raids, and infiltrations, staking out positions from which to attack and then reassemble civil society.

It is precisely in the popular cultural resistance that indigeneity plays an important political role. From the point of view of the Jewish state, "traditional" or "Arab" frames for social mobilization are not associated with challenging Jewish statehood or sovereignty. The main assault on the Palestinian claim of indigeneity comes rather from Israeli scholars who are embedded in the settler-colonial project and do all they can to deindigenize the Palestinians in the academic discourse. The Israeli government, on the other hand, is far more simplistic in its approach, and regards only clear-cut national framings of the struggle as a danger to the Jewish state. ${ }^{23}$ Although one should say that this is beginning to change: in part as a result of the effectiveness of cultural resistance and in part due to the Israeli political system moving further to the extreme right, indigenous cultural projects have been more systemically targeted since 2016 as constituting a threat to Israeli national security.

In this respect, it would be useful to note that cultural resistance can be political without being outwardly nationalistic. It has a political message even if it is not about gaining seats in parliament or winning elections, or seats, at the negotiation table. As the case studies below will illuminate, efforts to de-erase the settlercolonial state imprint, which has become the major focus of the cultural resistance inside Israel, are based on a sense of indigeneity. These current practices can be analyzed as a new shift of emphasis, one which also responds to the drastic changes of the past two decades. Protecting the indigeneity of the Palestinian people living inside Israel as a set of rights can be the principal cultural struggle against a regime that has the appearance, and some of the practices, of a liberal democracy, but in essence is not. Liberal democracy in the Israeli case has instead proven to be a tool of a settler-colonial movement that has not as yet completed its overall objective, namely its vision of a Jewish state in Palestine.

It is also worth noting that blurring national and indigenous struggles might be less detrimental to the national project than originally thought while being more beneficial to the community on the ground. As Stephen Duncombe remarks, with the immediacy of global media, the local becomes national and at the same time global: cultural resistance becomes a space for developing tools for political action, a dress rehearsal for the actual political act or a political action in itself, one which operates by redefining the meaning of politics. ${ }^{24}$ The potential relevance of this conception in the case of the perpetual Palestinian demand for the right of return is particularly poignant.

\section{De-Judaizing the Judaization}

The Israeli double project of indigenizing Jewish society while de-indigenizing the Palestinian minority in Israel began in 1948 and has not ceased. The Galilee is 
the main space where this double process has been taking place, the site of the Israeli government project of "Judaization of the Galilee." In this Israeli campaign, the Galilee is presented as a cradle of the Jewish nation, articulating one narrative while seeking to obliterate another. The Judaization of the Galilee necessitates not only settling the Galilee with Jews, but also altering the landscape so that Jews will no longer be considered settlers in the Palestinian Galilee. The establishment of national parks around sites that were regarded as important for the Jewish national historical narrative served to foster a Jewish self-perception of indigeneity.

The Judaization of the Galilee is portrayed officially as a successful transformation of the Jews in the region into the indigenous population in the Galilee, and the transmutation of the native Palestinians into settlers. However, if in this narrative the Galilee was perceived as an ancient Jewish land that was to be redeemed by its native sons, there was a functional need to leave intact those parts of the landscape that signify the antiquity of the Galilee, even if these were located in emptied Palestinian villages and quarters. This revision of spatial narrative thus produced a paradoxical reality: the venues in which much of the indigenous cultural resistance in the Galilee takes place are located within Israeli tourist sites. Thus, for instance, the ancient archaeological sites of Safuriyya and Bir'im are the spaces in which young Palestinians chose to declare their right of return as a second generation of internal refugees.

So far, the indigenous resistance movement is not counted for much by the Israelis themselves and this is the reason why it can still prosper and be expanded. The focus of Palestinian counter policy is the commemoration of the catastrophe, the Nakba. It consists of efforts to reconstruct life and landscape as it was before the catastrophe. Israel does not regard 1948 as a catastrophe, but for now it also does not see the connection between the reconstruction of erased life before 1948 and the commemoration of the catastrophe. In recent years though, Israel has enacted a new policy that entails closing access to material in its archives that deals with the Nakba and has put serious hurdles in the way of the attempts of Palestinians in Israel to commemorate the Nakba. That being said, such commemorations are still allowed and are largely carried out by the younger generation of the Palestinians in Israel.

Palestinians' use of indigeneity as a powerful motif can been seen in the kinds of projects activists have been initiating in various domains, such as art, education, and architecture, among others, as part of a cultural resistance that is deeply political. These initiatives, some of which are described below, are indicative of a bottom-up, daily, and nondramatic resistance to a Jewish state determined to wipe out the Palestinian indigeneity.

\section{Graffiti}

The theoretical literature on graffiti depicts it as an urban and suburban phenomenon but in Israel and Palestine it is mainly rural. Scholars writing about youth 
graffiti usually see it as part of youth delinquency. Among the Palestinians in Israel it is precisely the opposite-graffiti is a manifestation of the commitment and struggle of Palestinian youth. It is possible, however, to argue, in line with some of the general literature, that graffiti represents a means to share values, ethics, and codes of behavior via where and how it is produced.

In several villages in the Galilee murals painted on private homes and public buildings draw the pre-1948 village scenery. Once they were drawn in one village, they were emulated elsewhere. They are drawn by local artists, encouraged by cultural NGOs and local municipalities. The murals convey a very clear message: different communities coexisted in peace before the Nakba. In many ways, the murals are a virtual attempt to reruralize a community that was long ago forced to abandon agriculture and commerce as a way of life. ${ }^{25}$

\section{Reconstructing the Palestinian "Home"}

In 1948, half of Palestine's villages were destroyed within nine months of the Nakba. The lost Palestinian villages are not the same villages that can been seen today all over Israel/Palestine. The pre-1948 Palestinian village was a place where people of different religions lived together, where agriculture was the main source of subsistence. The village was organically connected to the ecological cycle of life in the country, respecting its flora and fauna, utilizing its water resources and natural herbs well and responsibly, and built according to the topography and climate of each region.

In 2017, the cultural NGO al-Manar (situated in Majdal Krum), together with the firm al-Arkan (located in Kabul), embarked on a unique project that seeks to reconstruct the heritage of Palestine as a legacy for the future. The project is called Hadara ("civilization") and focuses on the reconstruction of archetypal pre1948 Palestinian villages. In some villages, such as Kefar Yasif, murals were painted and the village piazza and residences were reconstructed. In some houses, people scraped away new mortar covering old walls in order to restore the old style of building, which provided cool houses in the summer and warm ones in the winter. Very few architects or builders today are capable of building in such a way-an artisanship that was lost, together with other cultural knowledge, in the Nakba.

The uniqueness of this project lies in the fact that the reconstructions were accomplished with materials that came directly from the destroyed villages: organic, authentic, natural materials that are part of the Palestinian heritage. The reconstructed villages were built with the support of eyewitnesses from the period, as well as their photographs and narratives. The terraces were built with stones from the destroyed villages; trees and herbs were extracted from the original sources. Even the coloring of the houses was sourced from local natural resources. A group of highly professional artisans from Russia and the Ukraine, with local architects and historians, have also helped to make models of these reconstructions that were distributed in recent years to the public. These models were supplied to 
more than one hundred Palestinian schools in Israel and the West Bank. In each they are placed at the entrance of the school, surrounded by posters that highlight aspects of pre-1948 rural Palestine.

Meanwhile, a number of Palestinian individuals and NGOs are working on having old Palestinian houses-the few that remain in urban spaces-recognized as UNESCO heritage sites. In downtown Haifa, local organizations are trying to dissuade the local municipality from demolishing these houses, such as the house of Emil Touma, who was one the leading intellectuals and journalists of the late Mandate and early Israeli statehood periods.

These projects of rehabilitation of houses and villages may appear cultural in nature, since they do not focus on sovereignty or liberation. They remain political insofar as they attempt to commemorate and rectify the dislocation of the native population by reconstructing the architectural face of indigeneity.

\section{Indigeneity as Educational Resistance}

Education is another important space for indigenous resistance, a struggle for Palestinian autonomy in an educational system that has been under Israeli scrutiny since 1948. The Israeli secret service has long vetted teachers and school heads alike, while punishing whoever challenged the curriculum by teaching the Palestinian narrative. ${ }^{26}$ Today, activists need to navigate carefully between the regime's refusal to recognize the Palestinians in Israel as a national minority and the latter's own refusal to accept the imposed Zionist narrative of the Israeli educational system.

The importance of indigeneity for the struggle of Palestinians in Israel-and the role of education in that struggle-is clearly articulated in the "Vision Papers," composed by Palestinian political and intellectual elites inside Israel. These are four documents prepared and publicized by Palestinian NGOs in Israel in 2006 and 2007. In 2006, the first two were published by the NGO Musawa in Haifa and by the Follow-Up Committee (the main representative body of the Palestinian minority in Israel, composed of members of Knesset, all heads of local Arab councils and municipalities, and heads of NGOs). In 2007, Mada al-Karmil, the leading independent research center in Haifa, and Adalah, the leading legal NGO of Palestinians in Israel, published their own vision papers. All of these papers successfully articulate the Palestinian minority's political aspirations to be recognized as "a native national group" (and as a minority according to the relevant definitions in international law), who aspires to live in a democratic state as equal citizens. Several times they mention indigeneity as the main moral and legal basis for demanding equality and international protection. ${ }^{27}$

The authors of these documents demand "cultural educational autonomy," on the grounds that "the Arab Palestinians in Israel-as natives-have the right to run their own educational system." ${ }^{28}$ They elaborate these educational demands, arguing for a "territorial cultural statutory autonomy" and demanding the creation of a separate Arab educational authority within the Israeli Ministry of Education. ${ }^{29}$ 
The structures requested are familiar-they are borrowed from Canada and the Swedish minority in Finland. However, to understand why these efforts represent an affirmation of indigeneity and not just an affirmation of national rights, it is worth pointing out that in a way such a structure already exists; namely, a separate educational office for "Arabs" is part of the Israeli Ministry of Education, but it has a different cultural vision of what the "Arabs" need to learn than the Palestinians in Israel themselves do. Without the defining aspirations of the "Vision Papers" within the settler/indigenous binary, it would be very difficult to see any fundamental difference in the power relations between an Israeli Zionist Ministry of Education and its Arab educational office (as it is now) and an autonomous one (as envisaged in the "Vision Papers").

Meanwhile, the Follow-Up Committee expanded an effort begun in 2008 by an NGO, Ibn Khaldun, to "shadow" every textbook and official program of the Israeli Ministry of Education with a counter textbook and program, which teachers could use as they deemed right. For instance, when the Israeli Education Ministry provided a booklet of "One Hundred Basic Notions about Zionism" as part of the curriculum, Ibn Khaldun produced a counter, "One Hundred Basic Notions about Palestine." 30

There is not, as yet, comprehensive research on educational efforts by educators and parents in the Palestinian community to circumvent the official curriculum. It appears that widespread informal home-schooling provides an alternative narrative to the official one. There is also a local Palestinian academic effort to deconstruct the "Arab" school curriculum in Israel as a way to de-educate indigenous Palestinians. The danger of producing an overtly national narrative is being replaced by efforts to create a less conspicuous, indigenous one. It should be noted that while the liberal Zionist project tries hypocritically to universalize both the Jewish and Arab narratives (by stressing human and civil rights, but ignoring indigenous rights), Palestinian activists and NGOs focus on indigeneity as a cultural project from below, one that seeks to counter the erasure produced by the settler-colonial project's false universalizing mission.

\section{Indigenizing Segregated Spaces}

The "Vision Papers" devote considerable space to discussing land ownership and rights, which remain indeed the most pressing issue for the Palestinian community in Israel. In the early years of the state, the communist party led a national struggle to save Palestinian lands from an Israeli policy of expropriation, especially in the Galilee. The struggle continues today as a civic one, with a strong emphasis on how expropriation, and the severe difficulties of buying land, are violations of the indigenous rights of the minority.

There are, however, two ways of living in a mixed community nowadays in Israel. Palestinians who live in originally mixed towns are discriminated against at all levels of municipal and governmental services. There, the indigenous 
struggle is about regaining space for expansion according to the population's needs, demolishing segregation walls, safeguarding Arabic names of streets and neighborhoods, and overall improving the physical infrastructure. In Acre and Jaffa, for example, the struggle has been mainly against governmental policies of silent de-Arabization and transfer of Arab neighborhoods to Jewish ownership and identity. Ad hoc organizations help residents to remain steadfast, providing them with legal aid and attracting international attention to their plight and to the danger of their eviction. The town of Ramleh is a case in point. There, Palestinians are resisting a municipality that deems them aliens and mitrad"nuisance" in Hebrew, a term used for physical objects such as garbage. An NGO called al-Bayt ("Home") has succeeded in persuading the UNESCO to recognize some Palestinian buildings as cultural heritage sites. What remains ominous is the fact that the Palestinian neighborhoods in Ramleh are not included in the city's overall municipal strategic planning. ${ }^{31}$

The second way of challenging spatial segregation is seen in Palestinians moving into what were meant to be exclusively Jewish towns. There is no way of knowing how many Palestinians have succeeded in moving into towns and settlements in the Galilee that are designated by the state as exclusively Jewish. Approximately seventy thousand Palestinians are estimated to live in either officially Jewish spaces or traditionally Jewish neighborhoods in mixed towns. Also striking is the increase in the number of Jews living in Palestinian villages. This latter phenomenon is even more subversive, given the settler-colonial and segregating structure of present-day Israel. ${ }^{32}$ There is a socioeconomic dimension to both developments: poor Jews move to Arab areas because they are more affordable, while Palestinians who are higher earners move to exclusively Jewish spaces. The latter can afford paying double, and at times triple, the rent that Jewish house owners would demand from Jewish renters. Their wish to live in these particular spaces corresponds to the overall desire to remain within the pre-1967 Israel borders in the eventuality of a two-state solution being implemented.

The government has attempted to stop such developments. There is an explicit discourse in Israel, which is translated into recent legislation, about "saving" Jewish towns and settlements from further Palestinian "invasion." One such legal act was the Acceptance to Communities bill of 2011, which formalized the establishment of admission committees to review potential new residents of communities of up to four hundred family units in the Naqab and Galilee regions, where the Palestinian population in Israel is largely concentrated. The law's central intention is to prevent Palestinians from settling in Jewish communities.

\section{Commemoration as Cultural Resistance}

Following the failure of the 1991 Madrid Conference to broach the subject of refugees, the principal body representing the internal refugees in Israel (more than a quarter of a million people) founded a new NGO, the Association for the Defense of the Rights of the Internally Displaced in Israel (ADRID). Since 1998 it 
has organized an annual March of Return on Israel's Independence Day (which is celebrated according to the lunar Hebrew calendar), marching to the site of a different 1948-destroyed village each year, as a way to remind the Jewish public of Israel of the price the Palestinians paid for Jewish independence.

Starting in the early 1990s, the Palestinian community in Israel also began commemorating Nakba Day on May 15, like all other Palestinian communities in the world. These events are closely coordinated with other Palestinian groups in Palestine and beyond. The ceremonies organized by Palestinians in Israel prioritize the return of internally displaced refugees to their villages before the implementation of the general right of return for all the Palestinians.

Commemoration of the Nakba by Palestinian citizens of Israel is now a widespread annual act, manifested in a March of Return, by thousands of people, to one of the many destroyed 1948 villages. These marches are attended by all the Palestinian politicians and have become a focus of cultural, as well as political, struggle against the 2011 Israeli Nakba law, which prevents public funding to anyone who commemorates the 1948 events as the Nakba. It is also a day of solidarity with oppressed Palestinians elsewhere, in which speakers are invited by video call from Gaza to emphasize the joint struggle to remove the blockade and end the siege. The indigenous dimension of the commemoration is accentuated by the Jewish, in particular liberal Jewish, objection to it. One of the gurus of liberal Zionism, Professor Shlomo Avineri, criticized it as an act of delegitimizing the state, since he saw the commemoration as revealing the hidden national wish of Palestinian citizens to lay the foundation of a Palestinian state all over historical Palestine. ${ }^{33}$

ADRID's vision of the future is to create clear educational and cultural spaces in which to de-erase what was wiped out in the $1948 \mathrm{Nakba}$. They do this through constant exploration of the legal possibilities for return to demolished villages and for compensation. Their strategies, such as the demand for the collective memory of the Nakba to be part of the identity and ethos of any future political entity that would come out of a process of reconciliation and peace, are similar to those used in other indigenous struggles. The very term internal refugees emphasizes indigeneity and is capable of protecting Palestinian rights in the face of efforts to denationalize the Palestinian political struggle. The implications that such a denationalization would have for the struggle of Palestinians in refugee camps in Lebanon and Syria, as well as Palestinians who might find themselves in a new reality if Israel annexes Area C in the West Bank or the West Bank as a whole (as the option that would make the return to "only" the Palestinian state in the Occupied Territories irrelevant), would be major.

\section{CONCLUSIONS}

The international legitimacy that the Jewish state enjoys has pushed the Palestinian minority in Israel to use new frameworks in the political struggle for their rights. The political elite of this minority still operates with reference to the two-state 
solution; it sees the struggle inside Israel as concerned with protecting their collective national rights and encouraging democratization of the Israeli political system. However, the death of this solution and the formation of a de facto single state, a variation on the South African apartheid model, has brought changes in the civil and cultural struggle of the Palestinians inside Israel that might also affect those living in Jerusalem and Area $\mathrm{C}$ in the West Bank, areas which are incrementally being annexed to Israel.

The success of these Palestinian struggles inside Israel will continue to depend on the ways in which the Palestinian liberation project will be redefined to fit the new reality and thereby stop relying on nostalgic national notions of the 1960 and 1970s. While the Palestinian national political limbo persists, Palestinians activists inside pre-1967 Israel are stressing Palestinian indigeneity. They thus offer an alternative language to the banned demand for national Palestinian rights in Israel while highlighting both the continuous settler-colonial nature of the regime and possible ways toward decolonization.

Designing and teaching, even if informally, alternative school curricula, or organizing Nakba commemorations and return marches are struggles for indigeneity. They are particularly important in the face of Israel's attempts of indigenization, or Judaization, that not only come at the expense of the native Palestinian population but also are meant to continue their displacement and destitution. Thus space, place, and counter-settlements are the means of the modern-day struggle against the settler-colonial state, and not only against the occupation in the West Bank or the Gaza Strip. ${ }^{34}$ Although the Israeli unilateral annexation of large parts of the West Bank since 2000 blurs the boundaries of post- and pre-1967 Israel, it expands the options of struggle within the West Bank, or the part of it that would be annexed to Israel.

The Palestinian struggle is and will continue to be a struggle against the privileges granted to the settlers over the natives. However, as long as the democratic game is played in Israel, an Islamic movement can win (as it did in municipal and national elections) and create a countercultural religious space in the public arena, one that is both religious and national. Once Israel outlawed the Islamic movement, it became clear that countercultural spaces, defined in either national or Islamic terms, would not be tolerated by the state. The Islamic movement has moved since then towards claiming religious spaces as "traditional" and "Islamic cultural" centers as part of their indigenous rights. This move must be read as a strategy of survival against, rather than submission to, Israeli settler-colonial erasure policies. Such cultural resistance, as has been shown, is daily, routine, and everywhere. It is performed in community centers, in youth and football clubs, in the sites of informal education, and in plays and films. ${ }^{35}$

It is too early to tell whether present-day Israel, with it nationalist and extremist ideology, will try to block any activity that is defined as indigenous and label it as either nationalist or terrorist. Demanding normality may seem a modest claim 
from a radical perspective that continues to insist on national liberation defined in terms of exclusive political sovereignty. The demand for normality, however, is existential given the ongoing setter-colonial reality. Unlike the political elites on both sides who associate demands for equality with grand political solutions, the daily cultural struggles of Palestinians who have lived in Israel for more than seventy years are centered on the demand for equality now in the name of civic and indigenous rights. Theirs is a struggle for equality as much as it is for national liberation. It goes beyond the demand for equal rights; it is an antidote to the dehumanization ingrained in a settler-colonial project-a call for humanizing the Palestinians in Israel.

\section{NOTES}

Parts of this chapter are drawn from Ilan Pappe, "Indigeneity as Resistance: Notes on the Palestinian Struggle within Twenty-First-Century Israel," South Atlantic Quarterly 117, no. 1 (2018): 157-78.

1. Yasser Arafat, "An Interview with Yasser Arafat," by Scott MacLeod, New York Review of Books, June 11, 1987.

2. James Clifford, "Indigenous Articulations," The Contemporary Pacific 3, no. 2 (2001): 468-90.

3. See for example, Ahmad Amara, Ismael Abu-Saad, and Oren Yiftachel, eds., Indigenous (In) Justice: Human Rights Law and Bedouin Arabs in the Naqab/Negev (Cambridge, MA: Harvard Law School Publications, 2012) and in particular the chapter there by Rodolfo Stavenhagen and Ahmad Amara, "International Law of Indigenous Peoples and the Naqab Bedouin Arabs," 158-93.

4. A point discussed at length by Oren Yiftachel, "Epilogue: Studying Naqab/Negev Bedouins -Towards a Colonial Paradigm?” HAGAR: Studies in Culture, Polity and Identities 8, no. 2 (2008): $83-108$.

5. Mansour Nasara, "The Ongoing Judaisation of the Naqab and the Struggle for Recognizing the Indigenous Rights of the Arab Bedouin People," Settler Colonial Studies 2, no. 1 (2012): 81-107.

6. Nadim N. Rouhana, "Homeland Nationalism and Guarding Dignity in a Settler-Colonial Context: The Palestinian Citizens of Israel Reclaim their Homeland," Borderland e-Journal 14, no. 1 (2015).

7. Edward Said, Culture and Imperialism (New York: Vintage Books, 1993), xiv.

8. Ahmad Amara, "Indigeneity in Palestinian Studies: Between Political and Legal Indigeneity," paper presented at the 2016 Palestinian Studies Workshop, Brown University, https://palestinianstudies .files.wordpress.com/2015/12/amara-ahmad.docx, 3.

9. Rena Barakat, "Writing/Righting Palestine Studies: Settler Colonialism, Indigenous Sovereignty and Resisting the Ghost(s) of History," Settler Colonial Studies 8, no. 3 (2018): 349-63.

10. Mahmoud Mamdani, "Settler Colonialism: Then and Now," Critical Inquiry 4, no. 3 (2015): 596-614.

11. Elizabeth Povinelli, The Cunning of Recognition: Indigenous Alterities and the Making of Australian Multiculturalism (Durham, NC: Duke University Press, 2002); Audra Simpson, Theorizing Native Studies (Durham, NC: Duke University Press, 2014).

12. Eric Cheyfitz, "Response to Steven Saliata's Inter/Nationalism from the Holy Land to the New World: Encountering Palestine in American Indian Studies," Native American and Indigenous Studies 1, no. 2 (2014): 145-47.

13. Rouhana, "Homeland Nationalism." See also Clifford, "Indigenous Articulations."

14. 'Azmi Bishara, "On the Question of the Palestinian Minority in Israel," Theory and Criticism 3 (1993): 7-21 [Hebrew]. See Maha Nassar, Brothers Apart: Palestinian Citizens of Israel and the Arab World (Stanford: Stanford University Press, 2017). 
15. Bishara, "On the Question of the Palestinian Minority in Israel."

16. There is not yet a census of how many Palestinians from Israel work, study, and live in the West Bank, but their growth is exponential

17. In the Philippines, for instance, indigenous struggles resulted in a legal reform in the country's laws of land ownership, while in Ecuador they contributed to change in the civil rights agenda and land reform. For more details see Jose Mencio Molinatas, "The Philippine Indigenous Peoples' Struggle for Land and Life: Challenging Legal Texts, Arizona," International and Comparative Law 21, no. 1 (2004): 269-303; and Karla Peña, "The Struggle for Land Reforms ad Food Sovereignty in Ecuador," Telesur, August 20, 2015, https://www.telesurenglish.net/opinion/The-Struggle-for-Land -Reforms-and-Food-Sovereignty-in-Ecuador-20150820-o014.html.

18. Samih al-Qassem and Mahmoud Darwish, A Correspondence between the Two Halves of the Orange (Haifa: Kul al-Arab, 1990).

19. Steven Salaita, Uncivil Rites (Chicago: Haymarket Books, 2015).

20. See US Campaign for Palestinian Rights, "From Palestine to Mexico, All the Walls Have Got to Go," https://uscpr.org/nowalls, accessed May 2021.

21. Roland Bleiker, Popular Dissent, Human Agency and Global Politics (Cambridge: Cambridge University Press, 2000), 278.

22. Antonio Gramsci, Prison Notebooks, eds. Quentin Hoare and Geoffrey Nowell Smith (New York: International, 1971), 229-39.

23. In this respect should be noted the importance of the volume edited by Rebecca L. Stein and Ted Swedenburg, Palestine, Israel and the Politics of Political Culture (Durham, NC: Duke University Press, 2005), which opened the way for seeking the role of cultural studies in general, and popular culture in particular, by examining the Palestinian case study. In a similar vein, the role cultural resistance plays beyond national or political boundaries was recognized earlier by Helga Tawil-Souri, "Towards a Palestinian Cultural Studies," Middle East Journal of Communication and Culture 2, no. 2 (2009): 181-85.

24. Stephen Duncombe, "Introduction," in Cultural Resistance Reader, edited by Stephen Duncombe, 1-16 (London: Verso, 2002).

25. Majid al-Haj, Education, Empowerment and Control: The Case of Arabs in Israel (Albany: State University of New York Press, 1995), 16-17.

26. Such as banishment for long periods from their villages or towns and imprisonment.

27. Follow-up Committee of the Arabs in Israel, "The Future Vision of the Palestinian Arabs in Israel," 10 [in Hebrew], available at http://www.reut-institute.org/he/Publication.aspx? PublicationId $=1428$.

28. As'ad Ghanem and Mohanad Mustafa, "The Future Vision as a Collective Political and Theoretical Platform of the Palestinians in Israel," in Between Vision and Reality: The Vision Papers of the Arabs in Israel 1006-2007, edited by Sarah Ozacky-Lazar and Mustafa Kabha, 156-87 (Jerusalem: Citizens' Accord Forum, 2009) [in Hebrew].

29. Follow-up Committee of the Arabs in Israel, "The Future Vision of the Palestinian Arabs in Israel," 25 .

30. Asad Ghanem, "Identity and Belonging': A Pioneering Project, Which Must be the Starting Point for an Alternative, Comprehensive Educational Plan," Adalah Newsletter 27 (July-August 2006), www.adalah.org/uploads/oldfiles/newsletter/eng/jul-augo6/ar2.pdf.

31. Ghazi Falah, Michael Hoy, and Rachel Sarker, "Co-existence in Selected Mixed Arab-Jewish Cities in Israel: By Choice or by Default," Urban Studies 37, no. 4 (2000): 775-96.

32. Yediot Achronot, April 27, 2013.

33. Shlomo Avineri, "A Jewish State of all its Citizens," Haaretz, October 6, 2012.

34. Rouhana, "Homeland Nationalism."

35. When the only Palestinian theater in Israel attempted to adopt a more national repertoire, it was faced with the wrath of the Minister of Culture, Miri Regev, as was the Arab-Hebrew Theatre in Jaffa for similar "offences." 


\section{BIBLIOGRAPHY}

al-Haj, Majid. Education, Empowerment and Control: The Case of Arabs in Israel. Albany: State University of New York Press, 1995.

al-Qassem, Samih, and Mahmoud Darwish. A Correspondence between the Two Halves of the Orange. Haifa: Kul al-Arab, 1990. [Arabic.]

Amara, Ahmad. "Indigeneity in Palestinian Studies: Between Political and Legal Indigeneity." Paper presented at the 2016 Palestinian Studies Workshop, Brown University. https://palestinianstudies.files.wordpress.com/2015/12/amara-ahmad.docx 2016.

Amara, Ahmad, Ismael Abu-Saad, and Oren Yiftachel, eds. Indigenous (In)Justice: Human Rights Law and Bedouin Arabs in the Naqab/Negev. Cambridge, MA: Harvard Law School Publications, 2012.

Barakat, Rena. "Writing/Righting Palestine Studies: Settler Colonialism, Indigenous Sovereignty and Resisting the Ghost(s) of History." Settler Colonial Studies 8, no. 3 (2018): 349-63.

Bleiker, Roland. Popular Dissent, Human Agency and Global Politics. Cambridge: Cambridge University Press, 2000.

Bishara, 'Azmi. "On the Question of the Palestinian Minority in Israel." Theory and Criticism (1993) 3: 7-21. [Hebrew.]

Cheyfitz, Eric. "Response to Steven Saliata's Inter/Nationalism from the Holy Land to the New World: Encountering Palestine in American Indian Studies." Native American and Indigenous Studies 1, no. 2 (2014): 145-47.

Clifford, James. “Indigenous Articulations." The Contemporary Pacific 3, no. 2 (2001): 468-9o.

Duncombe, Stephen. "Introduction." In Cultural Resistance Reader, edited by Stephen Duncombe, 1-16. London: Verso, 2002.

Falah, Gahzi, Michael Hoy, and Rachel Sarker. "Co-existence in Selected Mixed ArabJewish Cities in Israel: By Choice or by Default." Urban Studies 37, no. 4 (2000): 775-96.

Follow-up Committee of the Arabs in Israel. "The Future Vision of the Palestinian Arabs in Israel" [in Hebrew]. Available at http://www.reut-institute.org/he/Publication.aspx? PublicationId $=1428$.

Ghanem, As'ad, and Mohanad Mustafa. "The Future Vision as a Collective Political and Theoretical Platform of the Palestinians in Israel." In Between Vision and Reality: The Vision Papers of the Arabs in Israel 1006-2007, edited by Sarah Oszacky-Lazar and Mustafa Kabha, 156-87. Jerusalem: Citizens' Accord Forum, 2009.

Gramsci, Antonio. Prison Notebooks. Edited by Quentin Hoare and Geoffrey Nowell Smith. New York: International, 1971.

Jamal, Amal. Arab Minority in Israel: The Politics of Indigeneity. Abingdon: Routledge, 2011. Mamdani, Mahmoud. "Settler Colonialism: Then and Now." Critical Inquiry 4, no. 3 (2015): 596-614.

Molinatas, Jose Mencio. “The Philippine Indigenous Peoples' Struggle for Land and Life: Challenging Legal Texts, Arizona." International and Comparative Law 21, no. 1 (2004): 269-303.

Nasasra, Mansour. "The Ongoing Judaisation of the Naqab and the Struggle for Recognising the Indigenous Rights of the Arab Bedouin People." Settler Colonial Studies 2, no. 1 (2012): 81-107.

Nassar, Maha. Brothers Apart: Palestinian Citizens of Israel and the Arab World. Stanford, CA: Stanford University Press, 2017. 
Povinelli, Elizabeth. The Cunning of Recognition: Indigenous Alterities and the Making of Australian Multiculturalism. Durham, NC: Duke University Press, 2002.

Rouhana, Nadim, "Homeland Nationalism and Guarding Dignity in a Settler-Colonial Context: The Palestinian Citizens of Israel Reclaim Their Homeland." Borderland e-Journal 14, no. 1 (2015).

Said, Edward. Culture and Imperialism. New York: Vintage Books, 1993.

Salaita, Steven. Uncivil Rites. Chicago: Haymarket Books, 2015.

Simpson, Audra. Theorizing Native Studies. Durham, NC: Duke University Press, 2014.

Stavenhagen, Rodolfo, and Ahmad Amara. "International Law of Indigenous Peoples and the Naqab Bedouin Arabs." In Indigenous (In)Justice: Human Rights Law and Bedouin Arabs in the Naqab/Negev, edited by Ahmad Amara, Ismael Abu-Saad, and Oren Yiftachel, 158-93. Cambridge, MA: Harvard Law School Publications, 2012.

Stein, Rebecca L., and Ted Swedenburg. Palestine, Israel and the Politics of Political Culture. Durham, NC: Duke University Press, 2005.

Tawil-Souri, Helga. “Towards a Palestinian Cultural Studies." Middle East Journal of Communication and Culture 2, no. 2 (2009): 181-85.

Veracini, Lorenzo. Israel and Settler Society. London: Pluto Press, 2006.

—. "The Other Shift: Settler Colonialism, Israel and the Occupation." Palestine Studies 42, no. 2 (2013): 26-42.

Yiftachel, Oren. "Epilogue: Studying Naqab/Negev Bedouins: Towards a Colonial Paradigm?" HAGAR: Studies in Culture, Polity and Identities 8, no. 2 (2008): 83-108. 